\title{
Polarographic Catalytic Hydrogen Current Produced by Myoglobins and Hemoglobins ${ }^{\dagger}$
}

\author{
Hideaki Kinoshita, ${ }^{*}$ Tokuji IKEDA, Yoshiyuki YamanE ${ }^{\dagger \dagger}$ \\ and Mitsugi SENDA \\ Department of Agricultural Chemistry, Kyoto University, Sakyo-ku, \\ Kyoto 606, Japan \\ *Department of Chemistry, Kwassui Women's College, Higashi-yamate, \\ Nagasaki 850, Japan \\ Received March 21, 1980
}

\begin{abstract}
Sperm whale myoglobin, horse myoglobin, bovine hemoglobin, and human hemoglobin produced well-defined catalytic hydrogen current (Brdička current) in buffer solutions containing cobalt salts at dme and hmde. The Brdička current-activity of the myoglobins was shown to be due to the heme group and that of the hemoglobins to both the heme groups and SH groups in the molecule. The Brdička current produced by human hemoglobin was reduced by the addition of 2,3diphosphoglycerate (DPG), indicating that the formation of a hemoglobin-DPG complex resulted in the reduction of the Brdička current-activity of the protein.
\end{abstract}

Since the discovery of polarographic catalytic hydrogen current (Brdička current) produced by proteins in the presence of cobalt salts, the catalytic effect has been ascribed to $\mathrm{SS}$ or $\mathrm{SH}$ groups in the molecule. ${ }^{1,2)}$ However, we have shown in two previous papers ${ }^{3,4}$ that the Brdička current produced by cytochrome $c$ is due to the heme moiety in the molecule, in which the two cysteine residues are linked to the heme group to form heme $\varepsilon$ and neither SS nor SH groups are present. Sperm whale myoglobin and horse myoglobin contain neither cystine nor cysteine in the molecule; ${ }^{5)}$ nevertheless, these myoglobins produce the Brdička current in ammoniacal buffers containing cobalt salts at mercury electrode. ${ }^{6)}$ Furthermore, the Brdička current-activity of myoglobin has been shown to be attributable to the heme group attached to the globin moiety. The Brdička current-activity of bovine and human hemoglobins, which contain both heme and SH groups, has also been shown to

+ Main parts of this work were presented at the Meeting of the Agricultural Chemical Society of Japan at Okayama, October 14, 1978.

it Present address: Research Laboratory of Kanegafuchi Chemical Industry Co., Takasago, Hyogo 676, Japan. be due to both heme and $\mathrm{SH}$ groups in the molecule. The results and discussion are presented in this paper.

\section{EXPERIMENTAL}

Materials. Sperm whale myoglobin (whale Mb, Sigma Chemical Co., Type II, lot No. M-0380), horse myoglobin (horse Mb, Sigma Chemical Co., Type III, lot No. M1882), bovine hemoglobin (bovine Hb, Sigma Chemical Co., Type I, lot No. H-2500), and human hemolgobin (human $\mathrm{Hb}$, Sigma Chemical Co., Type IV, lot No. H7379) were purchased and used without further purification. The purity of these proteins were checked by cellulose acetate membrane electrophoresis. Stock solutions, usually at $0.5 \%$ of protein, were stored at $5^{\circ} \mathrm{C}$. The concentrations were determined spectrophotometrically. ${ }^{5)}$ Absorption spectra showed that all the commercial hemoproteins were in their met-form. ${ }^{5)}$ Oxymyoglobin and oxyhemoglobin were prepared by reduction of these hemoproteins with sodium dithionite followed by dialysis. Apomyoglobin was prepared from whale $\mathrm{Mb}$ according to the method of Breslow." These proteins were identified by absorption spectroscopy, and their concentrations were determined spectrophotometrically. ${ }^{5,7)}$ All other chemicals were of the reagent grade and used without further purification.

Instruments. D.c. polarograms were recorded with a Yanagimoto P8 polarograph. The characteristics of the dropping mercury electrode (dme) were $m=1.43 \mathrm{mg} \mathrm{sec}^{-1}$ 
and $\tau=4.0 \mathrm{sec}$ at open circuit in ammoniacal buffer with a 74-cm height of mercury reservoir. Voltage sweep voltammograms were recorded with a Yanagimoto P8MS6C potentiostat with a built-in voltage sweep generator and a Riken Denshi F42C X-Y recorder. A Metrohm E410 hanging mercury drop electrode (hmde) was used, its surface area being $0.0187 \pm 0.0003 \mathrm{~cm}^{2}$.

Electrochemical measurements. All measurements were made in an $\mathrm{H}$-type cell immersed in a thermostat at $25^{\circ} \mathrm{C}$. Potentials were measured against a saturated calomel electrode (SCE). A buffer solution containing $0.1 \mathrm{M} \mathrm{NH}_{3}$, $0.1 \mathrm{M} \mathrm{NH}_{4} \mathrm{Cl}$, and $0.1 \mathrm{M} \mathrm{KCl}$ (pH 9.4, ionic strength 0.2 mol dm${ }^{-3}$ ) was used as the base solution, unless otherwise stated. Other details of the electrochemical measurements have been described in a previous paper. ${ }^{33}$

\section{RESULTS AND DISCUSSION}

\section{Myoglobins}

Figure 1 shows d.c. polarograms of (A) $2 \times 10^{-4} \mathrm{M}$ hexaamminecobalt(III) chloride $(\mathrm{Co}(\mathrm{III}))$ in the base solution and (B-D) whale $\mathrm{Mb}$ at three different concentrations in (A) at dme. Figure 2 shows voltage sweep voltammograms of (A) $2 \times 10^{-4} \mathrm{M}$ Co(III) in the base solution and (B-D) $3.0 \mu \mathrm{M}$ whale $\mathrm{Mb}$ in (A) at three different exposure times at hmde. As seen in these figures, well defined catalytic currents, i.e. Brdička currents, were observed with whale $\mathrm{Mb}$ in the potential region more negative than the potential of the $\mathrm{Co}$ (II) to $\operatorname{Co}(0)$ reduction step. In the presence of cobaltous chloride in place of $\mathrm{Co}$ (III), whale Mb gave also a Brdička current practically the same in shape as that observed in the presence of $\mathrm{Co}$ (III), but the former was slightly smaller than the latter. Sperm whale deoxymyoglobin gave the same Brdička current as sperm whale metmyoglobin.

The dependence of the Brdička currentintensity at a given potential on various factors such as the concentrations of whale $\mathrm{Mb}$ and Co(III), the drop time at dme, and the exposure time and the voltage sweep rate at hmde, was the same ${ }^{8)}$ as that of the Brdička current produced by SS- and/or SHcontaining proteins. ${ }^{89}$ Thus the Brdička current can be expressed by ${ }^{10}$

$$
i_{\mathrm{B}}=F A k_{\mathrm{B}} \Gamma f_{\mathrm{Co}}
$$

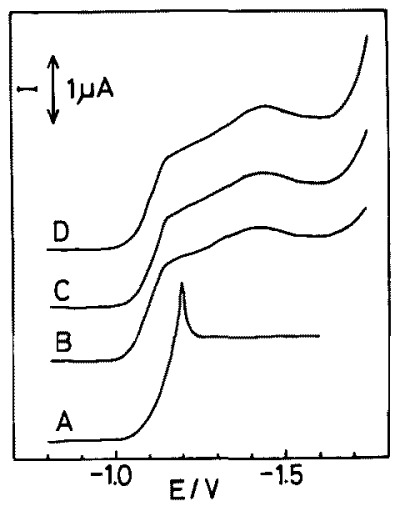

FIG. 1. d.c. Polarograms of (A) $2 \times 10^{-4} \mathrm{M} \mathrm{Co}$ (III) in the Base Solution and (B-D) Whale $\mathrm{Mb}$ in (A); Whale Mb Concentrations: (B) 1.5, (C) 3.0, and (D) $4.5 \mu \mathrm{M}$.

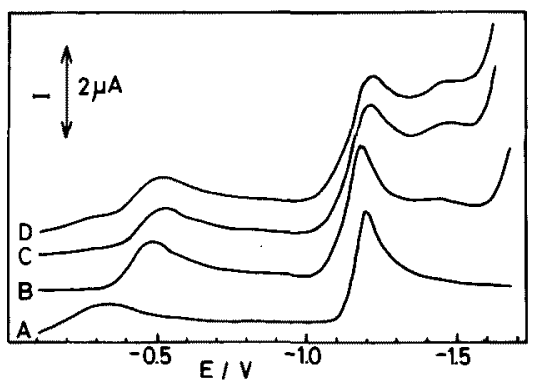

FIG. 2. Voltammograms of (A) $2 \times 10^{-4} \mathrm{M}$ Co(III) in the Base Solution and (B-D) $3.0 \mu \mathrm{M}$ Whale $\mathrm{Mb}$ in (A); Exposure Times: (B) 10, (C) 500, and (D) $1500 \mathrm{sec}$.

at low concentrations of $\mathrm{Co}$ (III), lower than $2 \times 10^{-4} \mathrm{M}$ in this case. Here $i_{\mathrm{B}}$ is the Brdička current, $F$ Faraday, $A$ the electrode surface area, $k_{\mathrm{B}}$ a constant representing the catalytic activity of the protein, $\Gamma$ the surface concentration of the protein (the number of moles per unit surface area) adsorbed on electrode surface, and $f_{\mathrm{Co}}$ the flux of cobalt ion at the electrode surface. The results also showed that $^{8)}$ the adsorption of whale $\mathrm{Mb}$ on the dme surface at $-1.4 \mathrm{~V}$ was controlled by diffusion at concentrations lower than $0.9 \mu \mathrm{M}$ of whale $\mathrm{Mb}$, so that $\Gamma$ was able to be estimated by the Koryta equation, ${ }^{11)}$ the diffusion coefficient $\left(D_{\mathrm{p}}\right)$ being given. ${ }^{12)}$ The cobalt ion flux is given by the Ilkovic theory. ${ }^{2)}$ Thus the $k_{\mathrm{B}}$ value of whale $\mathrm{Mb}$ was determined by applying Eq. 1 to the Brdička current at $-1.4 \mathrm{~V}$. The results are 
Table I. Polarographic Catalytic Activities at

$-1.4 \mathrm{~V}$ of Myoglobins and Hemoglobins IN AMMONIACAL BUFFERS AT pH 9.4

\begin{tabular}{|c|c|c|}
\hline \multirow{2}{*}{ Protein } & $D_{\mathrm{p}}$ & \multirow{2}{*}{$\frac{k_{\mathrm{B}}}{10^{12} \mathrm{~cm}^{2} \mathrm{~mol}^{-1}}$} \\
\hline & $\overline{10^{-7} \mathrm{~cm}^{2} \mathrm{~s}^{-1}}$ & \\
\hline \multicolumn{3}{|l|}{ Myoglobin } \\
\hline sperm whale & $11.3^{a}$ & 0.22 \\
\hline horse & $11.3^{121}$ & 0.22 \\
\hline \multicolumn{3}{|l|}{ Hemoglobin } \\
\hline bovine & $6.4^{a}$ & 3.6 \\
\hline human & $6.4^{(2)}$ & 8.7 \\
\hline
\end{tabular}

- The same $D_{\mathrm{p}}$ values as those of horse $\mathrm{Mb}$ and human $\mathrm{Hb}$ were assumed for sperm whale $\mathrm{Mb}$ and bovine $\mathrm{Hb}$, respectively.

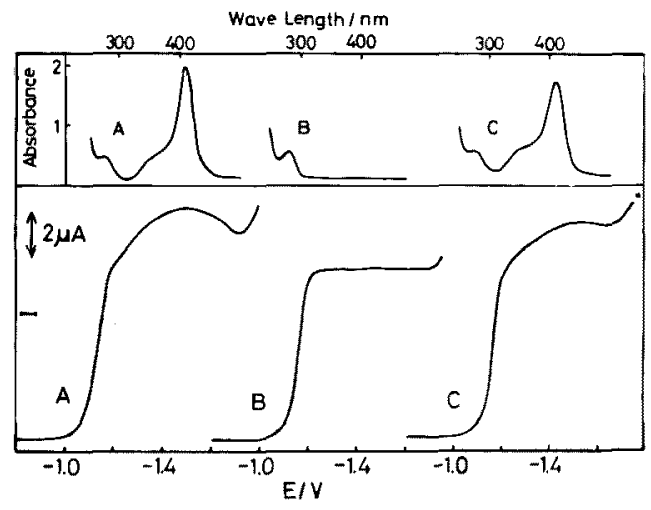

FIG. 3. Absorption Spectra and Polarograms of (A) Native Whale Metmyoglobin, (B) Apomyoglobin, and (C) Reconstituted Myoglobin Each at $15 \mu \mathrm{M}$ in the Base Solution Containing $8 \times 10^{-4} \mathrm{M} \mathrm{Co}$ (III).

given in Table $\mathrm{I}$.

Figure 3 shows absorption spectra and polarograms of (A) native metmyoglobin, (B) apomyoglobin, and $(C)$ reconstituted myoglobin from sperm whale. As seen in Fig. 3B, no Brdička current was observed with apomyoglobin. However, when an equivalent amount of hemin chloride was added to the apomyoglobin solution, the Brdička current was reproduced immediately after the addition of hemin chloride (Fig. 3C). The reproduced Brdička current was essentially the same as the Brdička current observed with native myoglobin (Fig. 3A). Absorption spec- trum of the apomyoglobin solution containing hemin chloride indicates the reconstitution of myoglobin from apomyoglobin and hemin (Figs. $3 \mathrm{~A}$ and $3 \mathrm{C})^{5,7)}$ The Brdička current was observed neither in solutions of hemin chloride alone, nor in solutions of hemin chloride containing protein having no SS and SH groups, such as $\alpha$-amylase from Bacillus subtilis (a product of Sigma Chemical Co., Type II-A, lot No. A6380) or sub-

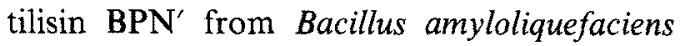
(a product of Sigma Chemical Co., Type VII, lot No. P5255). The results evidently indicate that the heme group attached to the globin moiety is essential to the appearance of the Brdička current of myoglobin.

Horse $\mathrm{Mb}$ gave the Brdička current practically the same as that of whale $\mathrm{Mb}$; the $k_{\mathrm{B}}$ $(-1.4 \mathrm{~V})$ value is given in Table I. Horse $\mathrm{Mb}$ gave the Brdička current also in an ammoniacal buffer at $\mathrm{pH} 9.0\left(k_{\mathrm{B}}(-1.4 \mathrm{~V})=0.16 \times 10^{12}\right.$ $\mathrm{cm}^{2} \mathrm{~mol}^{-1}$ ), and in tris (hydroxymethyl)aminomethane buffers (tris buffer) at $\mathrm{pH} 9.0$ $\left(k_{\mathrm{B}}(-1.4 \mathrm{~V})=0.14 \times 10^{12} \mathrm{~cm}^{2} \mathrm{~mol}^{-1}\right), \mathrm{pH}$ $8.0\left(k_{\mathrm{B}}(-1.4 \mathrm{~V})=0.10 \times 10^{12} \mathrm{~cm}^{2} \mathrm{~mol}^{-1}\right)$, and $\mathrm{pH} 7.0\left(k_{\mathrm{B}}(-1.4 \mathrm{~V})=0.07 \times 10^{12} \mathrm{~cm}^{2} \mathrm{~mol}^{-1}\right)$.

We have previously shown ${ }^{3,4)}$ that the Brdička current produced by cytochrome $c$ is due to the heme moiety of the molecule. An interesting common feature of the polarograms and voltammograms of the Brdička current produced by myoglobin and cytochrome $c$ is that the reduction step of $\mathrm{Co}$ (II) to $\mathrm{Co}(0)$ is little or only slightly (less than $\pm 30 \mathrm{mV}$ ) affected by the presence of these proteins (Figs. 1 and 2 and ref. 3). On the contrary, in the presence of SS- and/or SHcontaining proteins, the reduction step of $\mathrm{Co}(\mathrm{II})$ to $\mathrm{Co}(0)$ shows a large positive shift, as much as about $0.2 \mathrm{~V}^{1,9)}$ As to the $k_{\mathrm{B}}(-1.4 \mathrm{~V})$ value, however, there is a large difference between myoglobin $\left(k_{\mathrm{B}}(-1.4 \mathrm{~V})=0.22 \times 10^{12}\right.$ $\left.\mathrm{cm}^{2} \mathrm{~mol}^{-1}\right)$ and cytochrome $c\left(k_{\mathrm{B}}(-1.4 \mathrm{~V})^{3)}=\right.$ $4.2 \times 10^{12} \mathrm{~cm}^{2} \mathrm{~mol}^{-1}$ ).

As stated above, the Brdička current produced by metmyoglobin was the same as that by deoxymyoglobin. Scheller et al. ${ }^{13)}$ have reported that metmyoglobin is reduced to 
deoxymyoglobin at $-1.0 \mathrm{~V} v s$. SCE at dme, which is more positive than the potential where the Brdička current is produced. Therefore, we may conclude that the Brdička current produced by myoglobin is due to its deoxy-form.

\section{Hemoglobins}

Figure 4 shows d.c. polarograms of the Brdička current of (B) bovine $\mathrm{Hb}$ and (C) human $\mathrm{Hb}$ each at $0.4 \mu \mathrm{M}$ (as a tetramer) in the base solution containing $2 \times 10^{-4} \mathrm{M} \mathrm{Co}(\mathrm{III})$. The polarograms of the Brdička current produced by bovine $\mathrm{Hb}$ and human $\mathrm{Hb}$ were very similar in shape with each other except for a small hump observed with human $\mathrm{Hb}$ at an extremely negative potential, but rather different in current height. These Brdička currents were shown ${ }^{81}$ to follow Eq. 1; the $k_{\mathrm{B}}(-1.4 \mathrm{~V})$ values are given in Table I. Bovine $\mathrm{Hb}$ produced the Brdička current also in an ammoniacal buffer at $\mathrm{pH} 9.0\left(k_{\mathrm{B}}(-1.4 \mathrm{~V})=\right.$ $\left.2.6 \times 10^{12} \mathrm{~cm}^{2} \mathrm{~mol}^{-1}\right)$, tris buffers at $\mathrm{pH}$ $9.0\left(k_{\mathrm{B}}(-1.4 \mathrm{~V})=2.0 \times 10^{12} \mathrm{~cm}^{2} \mathrm{~mol}^{-1}\right), \mathrm{pH}$ $8.0 \quad\left(k_{\mathrm{B}}(-1.4 \mathrm{~V})=0.98 \times 10^{12} \mathrm{~cm}^{2} \mathrm{~mol}^{-1}\right)$, and $\mathrm{pH} 7.0 \quad\left(k_{\mathrm{B}}(-1.4 \mathrm{~V})=0.78 \times 10^{12} \mathrm{~cm}^{2}\right.$ $\left.\mathrm{mol}^{-1}\right)$, and a phosphate buffer at $\mathrm{pH} 7.0$ $\left(k_{\mathrm{B}}(-1.4 \mathrm{~V})=0.58 \times 10^{12} \mathrm{~cm}^{2} \mathrm{~mol}^{-1}\right)$.

Hemoglobin has four protohemes in a molecule (as a tetramer); the structure at the heme moiety is very similar to that of myoglobin. ${ }^{5)}$ Therefore the contribution of

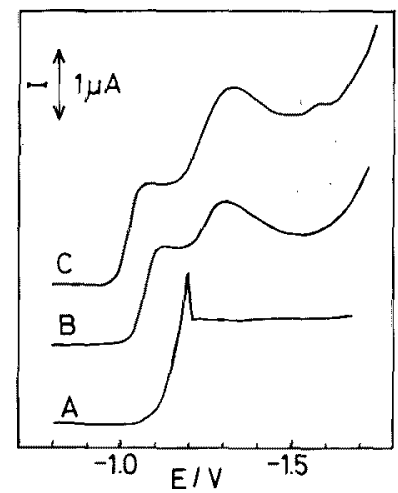

Fig. 4. d.c. Polarograms of (A) $2 \times 10^{-4} \mathrm{M} \mathrm{Co}$ (III) in the Base Solution and (B) Bovine $\mathrm{Hb}$ and (C) Human $\mathrm{Hb}$ Each at $0.4 \mu \mathrm{M}$ in $(\mathrm{A})$. these hemes to the $k_{\mathrm{B}}(-1.4 \mathrm{~V})$ value of bovine $\mathrm{Hb}$ and human $\mathrm{Hb}$ could be estimated as $4 \times\left(k_{\mathrm{B}}(-1.4 \mathrm{~V})\right.$ of myoglobin $)=0.88 \times 10^{12}$ $\mathrm{cm}^{2} \mathrm{~mol}^{-1}$. Bovine $\mathrm{Hb}$ and human $\mathrm{Hb}$ have two and six SH groups, respectively. ${ }^{5)}$ Therefore we can estimate the contribution of SH groups to the $k_{\mathrm{B}}(-1.4 \mathrm{~V})$ values as $(3.6-0.88) \times 10^{12} / 2=1.4 \times 10^{12} \mathrm{~cm}^{2} \mathrm{~mol}^{-1}$ and $(8.7-0.88) \times 10^{12} / 6=1.3 \times 10^{12} \mathrm{~cm}^{2}$ $\mathrm{mol}^{-1}$ per one SH group for bovine $\mathrm{Hb}$ and human $\mathrm{Hb}$, respectively. These $k_{\mathrm{SH}}(-1.4 \mathrm{~V})$ values per $\mathrm{SH}$ group are in good agreement with the $k_{\mathrm{B}}(-1.4 \mathrm{~V})$ value per $\mathrm{SH}$ group of $1.2 \sim 1.5 \times 10^{12} \mathrm{~cm}^{2} \mathrm{~mol}^{-1}$ for five globular SSand/or SH-containing proteins (bovine serum albumin, lysozyme, ribonuclease, trypsin, and pepsin). ${ }^{8)}$ The significant contribution of $\mathrm{SH}$ groups is evidenced also by the fact that the reduction step of $\mathrm{Co}(\mathrm{II})$ to $\mathrm{Co}(0)$ shows a large positive shift in the presence of bovine $\mathrm{Hb}$ and human $\mathrm{Hb}$ (Figs. 4B and 4C). In conclusion, the contribution of protoheme groups, though small compared with that of $\mathrm{SH}$ groups, should not be neglected to account for the Brdička current-activity of hemoglobins.

\section{Effect of 2,3-diphosphoglycerate on the Brdicka} current produced by human hemoglobin 2,3-Diphospholycerate (DPG) is widely pre-

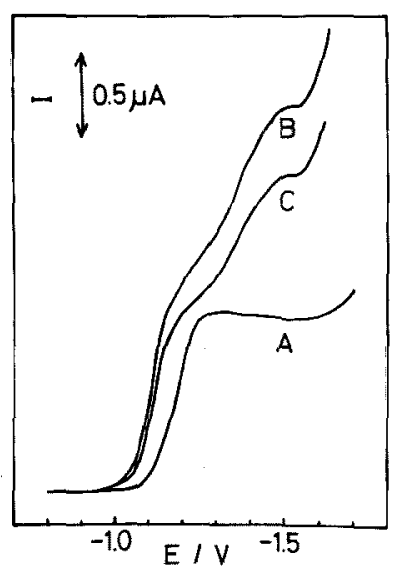

FIG. 5. d.c. Polarograms of (A) $2 \times 10^{-4} \mathrm{M} \mathrm{Co}$ (III) in $0.02 \mathrm{M}$ Phosphate Buffer of pH 7.0, (B) $1.0 \mu \mathrm{M}$ Human Deoxyhemoglobin in (A), and (C) $1.0 \mu \mathrm{M}$ Human Deoxyhemoglobin $+4 \times 10^{-4} \mathrm{M}$ DPG in (A). 


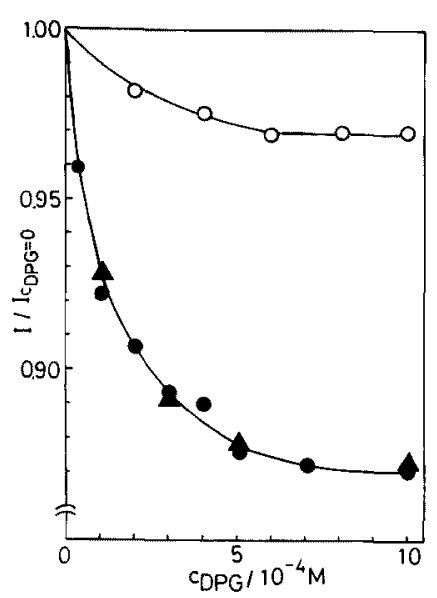

FIG. 6. Effect of DPG Concentration on the Brdička Currents Produced by Human Hemoglobin in (A) Met-, (O) Deoxy-, and (O) Oxy-forms.

sent in human and many other mammalian erythrocytes, and serves as an important allosteric regulator of hemoglobin function. ${ }^{14,15)}$ Interestingly, in the presence of DPG the Brdička current produced by human deoxyhemoglobin was reduced as shown in Fig. 5. Figure 6 shows the effect of DPG concentration on the Brdička currents produced by human hemoglobin in met-, deoxy-, and oxy-forms. The height of the Brdička current produced by mèthemoglobin and deoxyhemoglobin decreased to a certain limit with increasing concentrations of DPG. On the other hand, the height of the Brdička current produced by oxyhemoglobin was only slightly influenced by DPG. DPG has a strong tendency to form a complex with both methemoglobin and deoxyhemoglobin, but much less tendency with oxyhemoglobin. ${ }^{14)}$ Therefore, these results should be interpreted as that the formation of the complexes results in the reduction of the Brdička current-activity of this protein. Upon assuming, in the first approximation, that $i_{\mathrm{B}}=K_{\mathrm{B}}^{\prime}\left(\left(\alpha_{2} \beta_{2}\right)+(\alpha \beta) / 2\right)$ $+K_{\mathrm{B}}^{\prime \prime}$ (DPG- $\left.\alpha_{2} \beta_{2}\right), K_{\mathrm{B}}^{\prime}$ and $K_{\mathrm{B}}^{\prime \prime}$ being the proportionality constants, $\left(\alpha_{2} \beta_{2}\right),(\alpha \beta)$, and (DPG- $\alpha_{2} \beta_{2}$ ) the concentrations of tetramer, dimer, and DPG-hemoglobin complex, respectively, we estimated the binding constant of DPG to deoxyhemoglobin (also to methemoglobin) as $1 \times 10^{5} \mathrm{M}^{-1}$ in $0.02 \mathrm{M}$ phosphate buffer at $\mathrm{pH}$ 7.0. This value is in fair agreement with those obtained by other investigators; $1.5 \times 10^{5} \mathrm{M}^{-1}$ in $0.05 \mathrm{M}$ cacodylic buffer, $\mathrm{pH} 6.5,25^{\circ} \mathrm{C}$ (equilibrium dialysis method), ${ }^{16)} 6.7 \times 10^{4} \mathrm{M}^{-1}$ in solutions of $0.1 \mathrm{M}$ total chloride, $\mathrm{pH} 7.3,20^{\circ} \mathrm{C}$ (unltrafiltration method), ${ }^{17)}$ and $5.1 \times 10^{4} \mathrm{M}^{-1}$ in solutions of ionic strength $0.05, \mathrm{pH} 7.07,22.6^{\circ} \mathrm{C}$ (equilibrium dialysis method). ${ }^{18 \text { ) }}$

Acknowledgment. This work was supported by a Grant-in-Aid from the Ministry of Education (No. 411706).

\section{REFERENCES}

1) R. Brdička, Collect. Czech. Chem. Commun., 5, 112 (1933).

2) J. Heyrovský and J. Küta, "Principles of Polarography," Academic Press, New York and London, 1966.

3) T. Ikeda, H. Kinoshita, Y. Yamane and M. Senda, Bull. Chem. Soc. Jpn., 53, 112 (1980).

4) T. Ikeda, Y. Yamane, H. Kinoshita and M. Senda, Bull. Chem. Soc. Jpn., 53, 686 (1980).

5) E. Antonini and M. Brunori, "Hemoglobin and Myoglobin in Their Reactions with Ligands," NorthHolland, Amsterdam and London, 1971.

6) T. Ikeda, H. Kinoshita and M. Senda, Paper presented at the Polarographic Meeting, Oct. $7 \sim 8$, 1976, Nagano; Abstract, Rev. Polarogr. (Kyoto), 22, 75 (1976).

7) E. Breslow, J. Biol. Chem., 239, 486 (1964).

8) H. Kinoshita, Ph.D. Thesis, University of Kyoto, Kyoto, 1979.

9) M. Senda, T. Ikeda and H. Kinoshita, Bioelectrochem. Bioenerg., 3, 253 (1976).

10) H. Kinoshita, T. Ikeda, Y. Yamane and M. Senda, Paper presented at the Polarographic Meeting, Nov. 4 5, 1977, Osaka; Abstract, Rev. Polarogr. (Kyoto), 23, 16 (1977).

11) J. Koryta, Collect. Czech. Chem. Commun., 18, 206 (1953).

12) "CRC Handbook of Biochemistry," The Chem. Rubber Co., Cleaveland, Ohio, 1968.

13) F. Scheller, M. Jänchen, J. Lampe, H. J. Prümke, J. Blanck and E. Palecek, Biochim. Biophys. Acta, 412, 157 (1975).

14) R. E. Benesch and R. Benesch, "Advances in Protein Chemistry," Vol. 28, ed. by C. B. Anfinsen, J. T. Edsall and F. M. Richards, Academic Press, New York, San Francisco, London, 1974, p. 211.

15) H. Chiba and R. Sasaki, "Current Topics in Cellular Regulation," Vol. 14, Academic Press, New York, 
1978, p. 75 .

16) A. Chanutin and E. Herman, Arch. Biochem. Biophys., 131, 180 (1969).
17) R. E. Benesch, R. Benesch, R. Renthal and B. A. Bray, Nature (London), New Biol., 234, 174 (1971).

18) O. Amire, G. B. Ogunmola and J. G. Beetlestone, $J$. Biol. Chem., 253, 8554 (1978). 